\title{
Early infantile epileptic encephalopathies
}

\author{
Alberto Fois \\ From 70th Congress of the Italian Society of Pediatrics, Joint National Meeting SIP, SICuPP, SITIP \\ Palermo, Italy. 11-14 June 2014
}

Epileptiform abnormalities contribute to progressive deterioration of cerebral function. Considered: Ohtahara Syndrome; Early myoclonic epileptic encephalopathy; West Syndrome; Dravet Syndrome; Myoclonic status in not progressive encephalopathies; CDKL5 encephalopaty.

Ohtahara syndrome (OS) early infantile encephalopathy (EIEE). Most cases linked to cerebral malformations or very occasionally to metabolic disorders. Main seizures: tonic spasms, tonico- clonic, myoclonic and atonic and partial spasms. Treatment Vigabatrin, Topamax, Zonegran, Steroids, ACTH and Ketogenic diet, vagal stimulation and more invasive surgery. Mutations of the gene STBX1 (Sintaxin binding protein) Mutations of SPTA gene and GC1 have been reported. Prognosis is poor.

Early Myoclonic Encephalopathy (EME). Onset: neonatal period or first months of life. Seizures mainly erratic, myoclonic or partial, tonic spasms. EEG burst suppression. Etiology mostly unknown. Inborn errors of metabolism as nonketotic hyperglycinemia, or propionic acidemia reported . Prognosis poor. Therapy similar to that for OS.

West Syndrome (WS) aka as infantile spasms with hypsarrhythmia, EEG abnormality with asynchronous very high amplitude, irregular, continuous multifocal spike an slow wave discharges. In $80 \%$ of cases a cause can be found or suspected (symptomatic or criptogenethic)In about $20 \%$ of patients no cause can be found (idiopathic). 1:3200 / 1:3500 newborns. Causes: infections, cerebral malformations, hypoxic ischemic injuries, metabolic and genetic disorders, tuberosclerosis. Corticotropin considered effective. This finding later confirmed. No definite therapeutic scheme. High dose and long term treatment associated with hypertension, cuschingoid features and ipokalemia. Vigabatrin and Topiramate useful. Zonisamide, Lamotrigine and Levetiracetam can be used. Prognosis much better in idiopathic cases when treatment is started within the first month from the appearance of the symptoms.
Myoclonic status in nonprogressive encephalopathies. Rare, onset in the first years of life. Partial motor seizures, myoclonic absences or massive myoclonias sometimes with startles. Interictal EEG epileptiform discharges and background slowing. Described in genetic conditions like Angelman and $4 \mathrm{p}$ - syndromes. Prognosis poor.

Dravet syndrome (Severe myoclonic infantile epilepsy or SMEI). 1/500 cases of infantile epilepsy. Febrile convulsions in the first year. Subsequently myoclonic seizure with fever. Photosensitivity. In $70 \%$ of cases mutations of SCN1A gene. Difficult to treat. Topiramate, Clobazam, Stiripentol.

CDKL5 Encephalopathy. Mutations in the human X linked cyclin-dipendent kinase like 5 (CDKL5), infantile spasms and Rett (RTT) like phenotype. Initially normal EEG and severe hypotonia. Aquired microcephaly and hand stereotypes. Identified with early infantile epileptic encephalopathy 2. Prognosis severe.

Published: 11 August 2014

doi:10.1186/1824-7288-40-S1-A69

Cite this article as: Fois: Early infantile epileptic encephalopathies. Italian Journal of Pediatrics 2014 40(Suppl 1):A69.

Submit your next manuscript to BioMed Central and take full advantage of:

- Convenient online submission

- Thorough peer review

- No space constraints or color figure charges

- Immediate publication on acceptance

- Inclusion in PubMed, CAS, Scopus and Google Scholar

- Research which is freely available for redistribution

Submit your manuscript at www.biomedcentral.com/submit C BioMed Central
Siena, Italy
C 2014 Fois: licensee BioMed Central Ltd. This is an Open Access article distributed under the terms of the Creative Commons Attribution License (http://creativecommons.org/licenses/by/4.0), which permits unrestricted use, distribution, and reproduction in any medium, provided the original work is properly cited. The Creative Commons Public Domain Dedication waiver (http:// creativecommons.org/publicdomain/zero/1.0/) applies to the data made available in this article, unless otherwise stated. 